broth. After vigorous shaking the broths were incubated at $37^{\circ} \mathrm{C}$ for five days and were examined daily for bacterial growth.

\section{Results}

No evidence was obtained from either series of experiments that bacteria passed through the glove fingers that had been treated with monomer. The control experiments also gave negative results. The organisms in the broth cultures within the glove fingers remained viable over the course of the experiments.

\section{Comment}

Allergy to acrylic resins is well known. Sensitivity may be to the monomer or to one of the additives (Calnan and Stevenson, 1963). In the present case it seems evident that there is sensitivity to the methylmethacrylate itself and that the sensitivity to the benzoyl peroxide is of marginal importance. In medicine self-curing resin is used in orthopaedics in hip surgery (Charnley, 1970), in replacement arthroplasty of the elbow joint (Dee and Sweetnam, 1970), in a procedure to stabilize the spine (Knight, 1959), and in the treatment of intracranial aneurysms (Dutton, 1959).

The penetration of the rubber gloves was an unexpected finding and in fact delayed the diagnosis in this case. The clinical implications are twofold: firstly, that dermatitis and possibly toxic effects may occur as the result of penetration; and, secondly, that chemical damage to rubber gloves might allow bacterial penetration. From the dermatological point of view acrylic monomer can readily penetrate surgical rubber gloves and no doubt carry other substances with it, the same may well apply to acetone and other solvents. It is possible that some cases of dermatitis of the hands may have been incorrestly interpreted as the result of unawareness of the permeability of rubber. Such cases may have been diagnosed as rubber glove dermatitis, for inquiry among colleagues reveals that a number of cases of rubber glove dermatitis give negative patch tests to rubber and rubber additives. It is among surgeons and theatre staff dealing with acrylics that such factors operate, but there may be other situations involving other solvents.

As regards the bacteriology, under the conditions of the experiments reported above it seems that bacteria do not pass through treated gloves. Since B. subtilis and Staph. aureus could withstand the effects of monomer for one hour, had they passed through the glove fingers in the second series of experiments they should have been detected in the monomer surrounding the glove fingers. During the course of an operation, however, the stresses to which gloves are subjected are somewhat different from the situation in these experiments, since the surgeon would be exerting great pressure on the gloves when packing bone cavities with cement. The possibility that under these conditions organisms could be forced through the gloves into the tissues cannot be totally ruled out. It is possible that the untoward effects of monomer could be prevented by wearing heavy gauge rubber or polyvinyl chloride gloves during the appropriate stages of an operation.

We have pleasure in acknowledging the help and advice of Dr. R. H. Muller, of J. G. Franklin \& Sons Ltd., Mr. G. S. Thurman, of C.M.W. Laboratories Ltd., Mr. S. W. Rogers and Mr. E. R. Howells of I.C.I. and Professor C. F. Barwell, of the bacteriology department of the London Hospital Medical College. We also wish to thank Mrs. S. J. Fitzgerald, who helped in some of the bacteriological experiments.

\section{References}

Calnan, C. D., and Stevenson, C. J. (1963). Transactions of the St. Fohn's Hospital Dermatological Society, 49, 9.

Charnley, J. (1970). Acrylic Cement in Orthopaedic Surgery. Edinburgh, Livingstone.

Dee, R., and Sweetnam, D. R. (1970). Proceedings of the Royal Society of Medicine, 63, 653.

Dutton, J. (1959). British Medical fournal, 2, 597.

Kutton, J. (1959). British Medical

Lowbury, E. J. L., Lilly, H. A., and Bull, J. P. (1963). British Medical Fournal, 1, 1251 .

\title{
Lymphocyte Sensitization in Sarcoidosis
}

\author{
E. A. CASPARY, E. J. FIELD
}

British Medical fournal, 1971, 2, 143-145

\section{Summary}

Nineteen patients with sarcoidosis have all been shown to have lymphocytes in their blood sensitized to several antigens, including purified protein derivative of tuberculin and Kveim agent, though they had negative or greatly reduced Mantoux reaction. Two patients who repeatedly failed to "convert" after B.C.G. inoculation showed the same cell sensitization phenomena. No explanation can be offered for this anomaly.

\footnotetext{
Medical Research Council, Demyelinating Diseases Unit, Newcastle General Hospital, Newcastle upon Tyne NE4 6BE

E. A. CASPARY, M.SC., Member of M.R.C. Scientific Staff

E. J. FIELD, M.D., F.R.C.P., Professor of Experimental Neuropathology
}

\section{Introduction}

Some years ago we found increased antibody titre to a number of antigens in the serum of patients suffering from sarcoidosis (unpublished). The antigens tested comprised encephalitogenic factor (E.F.), a basic protein of histone-like character extracted from human brain (Caspary and Field, 1965); purified protein derivative of tuberculin (P.P.D.); bovine serum albumin; egg albumen; and cow vaginal mucus, the latter being an "exotic" antigen. Recently an electrophoretic method of assessing lymphocyte sensitization to different antigens has been developed (Field, Caspary, Hall, and Clark, 1970; Caspary and Field, 1971a) primarily for the study of "autoimmune" disease of the nervous system (Caspary and Field, 1971b). Among control subjects examined was one patient with sarcoidosis. Because of the unexpected results a small series was collected, which forms the subject of this preliminary communication. 


\section{Patients and Methods}

Nineteen patients with proved sarcoidosis were studied. All had positive Kveim tests and negative Mantoux reactions. As controls blood samples from six normal subjects and six nonsarcoid patients were examined. These were not matched for age and sex with the patients but extended over a wide age range. In addition, a large group of normal subjects were examined with some of the antigens (E.F., sciatic nerve basic protein (S.N.B.P.), and muscle) (see Field and Caspary, 1970 -Table III). Venous blood $(15 \mathrm{ml})$ was defibrinated with glass beads and a suspension of lymphocytes (98\% pure) obtained as described by Hughes and Caspary (1970), saccharated iron and methyl cellulose being used.

A suspension of guinea-pig macrophages in medium 199 was obtained by inoculating $20 \mathrm{ml}$ of sterile liquid paraffin into the peritoneum of healthy adult Hartley animals and washing out the peritoneum six to eight days later as described by Field et al. (1970). This macrophage exudate contained $10-20 \%$ lymphocytes. Before use it was subjected to 100 rads of $\gamma$-irradiation (see below) and the macrophage concentration finally adjusted to $10^{7} / \mathrm{ml}$. Antigens used were E.F., S.N.B.P., saline extract of human muscle, egg albumen, bovine serum albumin (B.S.A.), P.P.D., and Kveim antigen. In principle the method depends on the liberation of some factor(s) into the ambient medium when sensitized lymphocytes react with specific antigen. This factor, whose production involves protein synthesis (Caspary, 1971), slows the electrophoretic migration of normal guinea-pig macrophages in the medium. Thus normal guinea-pig macrophages are used as an indicator system for lymphocyteantigen interaction (Caspary and Field, 1971b).

The actual procedure has been described elsewhere (Field et al., 1970) and only a brief outline need be given. To $1 \mathrm{ml}$ of medium 199 containing $10^{7}$ guinea-pig macrophages $0.5 \times$ $10^{6}$ of the blood lymphocytes to be tested in $0.5 \mathrm{ml}$ of medium 199 are added, and the volume is made up to $3 \mathrm{ml}$ by the addition of a further $1.5 \mathrm{ml}$ of medium 199 (a suitable volume for use with the cytopherometer). The time of migration of the macrophages in this mixture-that is, without the presence of antigen-is measured as the "control time." The antigens to be tested are then added ( $33 \mu \mathrm{g}$ in $0.1 \mathrm{ml}$ ) and after 1.5 hours' incubation at $20^{\circ} \mathrm{C}$ the macrophage migration time is again estimated. In the presence of an antigen to which the human lymphocytes are sensitized the guinea-pig macrophages migrate more slowly. All measurements were limited to the guinea-pig macrophages-readily distinguishable under phase contrast illumination by their size and liquid paraffin droplet content-in a Zeiss cytopherometer. The migration of 10 cells was timed (to $0.1 \mathrm{sec}$ ) over a fixed distance in both directions of the potential difference $(180 \mathrm{~V}$; $7.5 \mathrm{~mA}$ ) so that a mean of 20 readings could be obtained. All specimens were coded and examined "blind" to eliminate observer bias. Results were expressed as a percentage change compared with the control time. Thus if $t_{c}=$ time of macrophage migration in control mixture-that is, in the absence of antigen-and $t_{e}=$ time of macrophage migration in presence of antigen, then $t_{e}-t_{c} \times 100$ was calculated in each case.

TABLE II-Normal Controls

\begin{tabular}{|c|c|c|c|c|c|c|}
\hline $\begin{array}{l}\text { Subject } \\
\text { No. }\end{array}$ & & Sex & Age & B.S.A. & $\begin{array}{c}\text { Egg } \\
\text { Albumen }\end{array}$ & Kveim \\
\hline $\begin{array}{ll}1 & \ldots \\
2 & \ldots \\
3 & \ldots \\
4 & \ldots \\
5 & \ldots \\
6 & \ldots\end{array}$ & $\begin{array}{l}\ldots \\
\cdots \\
\cdots \\
\ldots\end{array}$ & $\begin{array}{l}\text { F. } \\
\text { M. } \\
\text { F. } \\
\text { F. } \\
\text { F. } \\
\text { F. }\end{array}$ & $\begin{array}{l}23 \\
42 \\
45 \\
50 \\
54 \\
57\end{array}$ & $\begin{array}{r}2.5 \\
\text { N.T. } \\
1.2 \\
2.5 \\
-1.3 \\
1.9\end{array}$ & $\begin{array}{c}2 \cdot 7 \\
\text { N.T. } \\
1 \cdot 3 \\
1 \cdot 8 \\
2 \cdot 0 \\
2 \cdot 1\end{array}$ & $\begin{array}{r}-0.5 \\
0.2 \\
1.9 \\
1.7 \\
1.9 \\
0.5\end{array}$ \\
\hline
\end{tabular}

Normal subjects (see Field, and Caspary 1970)

$\begin{array}{ccc}\text { E.F. } & \text { B.P. } & \text { Muscle } \\ 2.5 \text { S.D. } 2.7 & 1.0 \text { S.D. } 1.7 & 1.1 \text { S.D. } 1.4 \\ (10.6 \text { to }-0.9) & (3.7 \text { to }-3.9) & (3.9 \text { to }-1.6)\end{array}$

*Number tested.

Some care is required in eliminating all "drift" in the cytopherometer before beginning a run. Experience has shown that such drift commonly arises from microleaks at joints and membranes. It is pointless to proceed until the machine is "behaving itself," and the maker's suggestion that two to three months' training is needed to master the machine is certainly true. Considerable patience may be required to achieve stability, but this may then endure for long periods.

TABLE I-Sarcoidosis

\begin{tabular}{|c|c|c|c|c|c|c|c|c|c|c|c|c|}
\hline \multirow{2}{*}{$\begin{array}{l}\text { Case } \\
\text { No. }\end{array}$} & \multirow{2}{*}{ Sex } & \multirow{2}{*}{ Age } & \multirow{2}{*}{ E.F. } & \multirow{2}{*}{ B.P. } & \multirow{2}{*}{ Muscle } & \multirow{2}{*}{ B.S.A. } & \multirow{2}{*}{$\begin{array}{c}\text { Egg } \\
\text { Albumen }\end{array}$} & \multirow{2}{*}{ P.P.D. } & \multirow{2}{*}{ Kveim } & \multicolumn{3}{|r|}{ Clinical Details } \\
\hline & & & & & & & & & & Mantoux & Kveim & \\
\hline 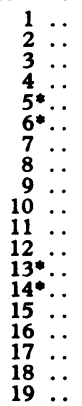 & $\begin{array}{l}\text { M. } \\
\text { M. } \\
\text { F. } \\
\text { M. } \\
\text { F. } \\
\text { F. } \\
\text { M. } \\
\text { F. } \\
\text { F. } \\
\text { F. } \\
\text { F. } \\
\text { F. } \\
\text { F. } \\
\text { M. } \\
\text { F. } \\
\text { F. } \\
\text { F. } \\
\text { M. } \\
\text { F. }\end{array}$ & $\begin{array}{r}8 \\
21 \\
30 \\
32 \\
37 \\
37 \\
39 \\
40 \\
40 \\
45 \\
49 \\
51 \\
57 \\
58 \\
60 \\
65 \\
67 \\
68 \\
80\end{array}$ & $\begin{array}{l}12.4 \\
17.3 \\
22.5 \\
16.6 \\
16.0 \\
18.0 \\
17.9 \\
20.2 \\
26.2 \\
21.5 \\
19.1 \\
16.8 \\
17.6 \\
18.3 \\
21.4 \\
19.8 \\
12.5 \\
18.1 \\
16.9\end{array}$ & $\begin{array}{l}17 \cdot 3 \\
17.7 \\
20.5 \\
18.8 \\
17.5 \\
16.9 \\
17 \cdot 4 \\
15.4 \\
21.9 \\
20.6 \\
16.1 \\
17.1 \\
18 \cdot 0 \\
18 \cdot 3 \\
15.3 \\
19.1 \\
21.6 \\
9.9 \\
15.5\end{array}$ & $\begin{array}{l}17.7 \\
16.1 \\
14.1 \\
17.9 \\
14.6 \\
11.1 \\
13.2 \\
25.0 \\
24.5 \\
18.3 \\
19.1 \\
18.8 \\
13.1 \\
13.5 \\
17.4 \\
14.2 \\
19.8 \\
13.7 \\
12.8\end{array}$ & $\begin{array}{l}19.1 \\
12.6 \\
13.9 \\
12.1 \\
16.9 \\
13.1 \\
15.6 \\
11.8 \\
\text { N.T. } \\
11.9 \\
15.0 \\
11.4 \\
12.2 \\
12.6 \\
16.2 \\
15.0 \\
20.9 \\
10.5 \\
12.9\end{array}$ & $\begin{array}{l}15.5 \\
17.2 \\
\text { N.T. } \\
14.2 \\
13.4 \\
12.9 \\
16.0 \\
10.4 \\
\text { N.T. } \\
\text { N.T. } \\
16.4 \\
\text { N.T. } \\
13.9 \\
12.8 \\
\text { N.T. } \\
13.4 \\
9.2 \\
17.8 \\
11.6\end{array}$ & $\begin{array}{l}16.7 \\
17.2 \\
19.5 \\
12.9 \\
17.7 \\
18.7 \\
19.5 \\
14.1 \\
19.4 \\
17.8 \\
16.7 \\
17.0 \\
15.5 \\
17.3 \\
12.7 \\
18.6 \\
15.7 \\
16.8 \\
17.4\end{array}$ & $\begin{array}{l}16.3 \\
13.0 \\
16.1 \\
20.6 \\
16.5 \\
11.1 \\
15.7 \\
23.4 \\
\text { N.T. } \\
\text { N.T. } \\
16 \cdot 4 \\
24.8 \\
10.7 \\
12.8 \\
\text { N.T. } \\
19 \cdot 8 \\
22.9 \\
16.0 \\
\text { N.T. }\end{array}$ & \begin{tabular}{|c|} 
Negative \\
Negative \\
Negative \\
Negative \\
Doubtful \\
Negative \\
Negative \\
Doubtful \\
Negative \\
Negative \\
Negative \\
Positive \\
Negative \\
Negative \\
Negative \\
Negative \\
Negative \\
Negative \\
Negative
\end{tabular} & $\begin{array}{c}\text { N.T. } \\
\text { N.T. } \\
\text { Positive } \\
\text { N.T. } \\
\text { N.T. } \\
\text { N.T. } \\
\text { N.T. } \\
\text { Positive } \\
\text { Positive } \\
\text { Positive } \\
\text { N.T. } \\
\text { Positive } \\
\text { N.T. } \\
\text { N.T. } \\
\text { Positive } \\
\text { Negative } \\
\text { Positive } \\
\text { N.T. } \\
\text { N.T. }\end{array}$ & $\begin{array}{l}\text { Pyrexia; sarcoid? glands } \\
\text { Pulmonary sarcoid } \\
\text { Pulmonary sarcoid } \\
\text { Sarcoidosis with liver involvement } \\
\text { Sarcoid glands } \\
\text { Pulmonary sarcoid } \\
\text { Pulmonary sarcoid } \\
\text { Sarcoidosis of face } \\
\text { Pulmonary sarcoid } \\
\text { Sarcoidosis of face; neurological signs } \\
\text { Sarcoidosis of skin; sarcoid nodules } \\
\text { Sarcoidosis of face } \\
\text { Pulmonary sarcoid } \\
\text { Pulmonary sarcoid } \\
\text { Sarcoidosis of face } \\
\text { Sarcoidosis of skin; sarcoid nodules } \\
\text { Sarcoidosis of face } \\
\text { Pulmonary sarcoid } \\
\text { Pulmonary sarcoid }\end{array}$ \\
\hline
\end{tabular}

N.T. $=$ Not tested.

TABLE III-Controls. Diseases other than Sarcoid

\begin{tabular}{|c|c|c|c|c|c|c|c|c|c|c|}
\hline $\begin{array}{l}\text { Case } \\
\text { No. }\end{array}$ & Sex & Age & E.F. & B.P. & Muscle & P.P.D. & Kveim & $\begin{array}{c}\text { Egg } \\
\text { Albumen }\end{array}$ & B.S.A. & \\
\hline $\begin{array}{ll}\text { II } & \cdots \\
\text { III } & \cdots \\
\text { IV } & \cdots \\
\text { vi } & \cdots\end{array}$ & $\begin{array}{l}\text { M. } \\
\text { M. } \\
\text { F. } \\
\text { F. }\end{array}$ & $\begin{array}{l}22 \\
25 \\
34 \\
39 \\
48 \\
67\end{array}$ & $\begin{array}{r}20 \cdot 0 \\
17 \cdot 8 \\
1 \cdot 2 \\
12 \cdot 0 \\
10 \cdot 4 \\
2 \cdot 0\end{array}$ & $\begin{array}{r}20 \cdot 0 \\
16 \cdot 9 \\
2 \cdot 0 \\
5 \cdot 6 \\
15 \cdot 1 \\
0 \cdot 7\end{array}$ & $\begin{array}{l}2 \cdot 1 \\
1.8 \\
2 \cdot 2 \\
1.5 \\
0 \cdot 2 \\
1.9\end{array}$ & $\begin{array}{l}22 \cdot 2 \\
19 \cdot 7 \\
19 \cdot 3 \\
16 \cdot 3 \\
15 \cdot 4 \\
18 \cdot 8\end{array}$ & $\begin{array}{l}1.2 \\
1.4 \\
0.6 \\
1.3 \\
0.4 \\
1.6\end{array}$ & $\begin{array}{r}2.9 \\
1.4 \\
2.5 \\
-0.7 \\
0.6 \\
2.0\end{array}$ & $\begin{array}{r}1.5 \\
2.0 \\
0.6 \\
-0.2 \\
1.1 \\
2.4\end{array}$ & $\begin{array}{l}\text { Giant cell tumour-3 years } \\
\text { Transverse myelitis; uveitis } \\
\text { No definite diagnosis } \\
\text { Carcinoma of ovary } \\
\text { Carcinoma of breast } \\
\text { No definite diagnosis }\end{array}$ \\
\hline
\end{tabular}


Preliminary experiment showed that the guinea-pig macrophage migration speed was reduced when human lymphocytes were added (without antigen) apparently from a "mixed lymphocyte" reaction taking place between the human cells and the $10-20 \%$ lymphocytes present in the guinea-pig macrophage exudate. After various attempts to separate the latter by differential centrifugation (Knowles and Hughes, 1970) it was finally found that the interfering reaction could be eliminated by 100 rads of $\gamma$-irradiation, which prevented the guinea-pig lymphocytes taking part in a mixed reaction with the human lymphocytes (while apparently retaining their viability). Macrophages were unaffected.

\section{Results}

Nineteen cases of sarcoid have so far been available for study and have shown strikingly similar results (Table I). In all cases the addition of any of the antigens to the human lymphocytes/guinea-pig macrophage mixture resulted in wellmarked slowing of the macrophages, indicating interaction of the antigen with the lymphocytes. In two instances this reaction was blocked by preliminary incubation of the control mixture with antilymphocytic serum, indicating the immunological nature of the interaction (Field et al., 1970; Caspary, Hughes, and Field, 1970). For comparison the results obtained in control patients are shown in Tables II and III.

As part of our control series two cases of Crohn's disease were studied. They, too, have lymphocyte sensitization to the antigens used in the present sarcoid work, though on the whole at a rather lower level. A more extensive series is being prepared. Six patients with disseminated lupus erythematosus were also studied and found to have the same sensitization as those with sarcoidosis.

\section{Discussion}

In a previous (unpublished) study made some years ago, as part of a control series for an investigation of antibody production in multiple sclerosis, it was noted that one laboratory worker among the control group unexpectedly showed circulating antibody to many different antigens. On examination she was found to have a shadow in a lung, and a diagnosis of sarcoidosis was finally made. A series of known sarcoidosis patients were examined and all showed similar raised antibody titres (unpublished). It was for this reason that the present work on cellular sensitization was undertaken. Though one report (Sands, Palmer, Maycock, and Creger, 1955) suggested that sarcoid patients produce a higher titre of isoagglutinins after small intravenous injections of mismatched blood cells than do controls, other work (reviewed by Scadding, 1967) has shown no consistent difference in antibody response. On the other hand, there is general agreement that a depressed ability to react with delayed skin responses is found in sarcoidosis (reviewed by Scadding, 1967).

Since delayed hypersensitivity is generally taken to reflect the presence of sensitized lymphocytes in the circulation it was expected that none would be found sensitized to P.P.D. in the cases of sarcoidosis with negative tuberculin reaction. Burnet (1959) indeed suggested that "the basic genetic character by which the [sarcoid] individual differs from the nor$\mathrm{mal}$ is almost the converse of agammaglobulinaemia. There is an abnormally efficient production of classical antibody and a poor development of the antibody-carrying cells (lymphocytes presumably) responsible for Mantoux reaction and the other manifestations of hypersensitivity" (p. 163). More recently
Burnet (1970) has written: "There has not been increase in the understanding of sarcoidosis since 1959."

The present work brings up a most interesting anomalythe existence of lymphocytes well sensitized to P.P.D. in the blood of patients who have a negative or much reduced Mantoux reaction. For this no explanation can at present be offered other than the occurrence of a depressing factor in serum.

The occurrence of lymphocyte sensitization to other antigens suggests that skin tests with these should also be carried out. It is remarkable that the Kveim antigen does not give an ordinary delayed tuberculin type reaction. The nature of the interfering mechanism is obscure. Of special interest are the four patients who have "recovered" from sarcoidosis (marked with asterisk on Table I). They still show sensitization not significantly different in degree from subjects with active sarcoidosis. This finding parallels that in malignant neoplasia (Field and Caspary, 1970) and again suggests that clones of lymphocytes once established may persist for many years. Patients with sarcoidosis differ from those with malignant neoplasia in that the latter show lymphocyte sensitization to central and peripheral nerve protein (E.F. and B.P.) only, while the former have sensitization to all antigens tested. (Table III).

The present study is being extended to subjects who have been found to be Mantoux negative and who do not convert after B.C.G. It might well be that such people, though apparently healthy, exhibit the immunopathology of sarcoidosis. So far we have had the opportunity of examining two subjects who have remained consistently Mantoux negative after repeated B.C.G. inoculations. Both have lymphocytes sensitized to the same antigens as sarcoid patients. Whether such subjects are "latent sarcoids" or the immunological phenomena are not fundamental to the diseaste demands further study. The similar findings in sarcoidosis, lupus, and Crohn's disease suggests a trial of further antigens which might enable differentiation between the immunological findings, especially in respect of the long-standing enigma of the relationship between sarcoidosis and Crohn's disease.

We gratefully acknowledge the helpful co-operation of our medical and surgical colleagues who have made available their patients under their care. In particular we wish to thank Drs. C. J. Stevenson, E. A. Spriggs, Peter Leggat, and J. R. Lauckner for referring well-documented cases of sarcoidosis for this preliminary study. We also thank Mr. A. Keith for his assistance in producing a constant supply of peritoneal macrophages and Mrs. J. Cunningham for her help in making lymphocyte preparations.

The cytopherometers used in this work were bought through the help of the Multiple Sclerosis Research Fund Limited and the North-East Multiple Sclerosis Society.

\section{References}

Burnet, F. M. (1959). The Clonal Selection Theory of Acquired Immunity London, Cambridge University Press.

Burnet, F. M. (1970). Self and Not Self. London, Cambridge University Press.

Caspary, E. A. (1971). Nature. In press. Caspary, E. A., and Field, E. J. (1965). Proceedings of the New York
Academy of Sciences, 122, 182.

Caspary, E. A., and Field, E. J. (1971a). European Neurology. In press.

Caspary, E. A., and Field, E. J. (1971b). Fournal of Clinical Pathology. In

press.
Caspary, E. A., Hughes, D., and Field, E. J. (1970). Clinical and Experimental Immunology, 7, 395.

Field, E. J., and Caspary, E. A. (1970). Lancet, 2, 1337

Field, E. ., Caspary, E. A., Hall, R., and Clark, F. (1970). Lancet, 1, 1144 Hughes, D., and Caspary, E. A. (1970). International Archives of Allergy,

37, 506.
Knowles, M., and Hughes, D. (1970). Fournal of Clinical Pathology, 23, 824.

Knowles, M., and Hughes, D. (1970). Fournal of Clinical Pathology, 23, 824. American fournal of Medicine, 19, 401.

Scadding, J. G. (1967). Sarcoidosis. London, Eyre and Spottiswood. 